\title{
Susan Petrilli named seventh Thomas A. Sebeok Fellow of the Semiotic Society of America
}

\author{
Frank Nuessel $^{1}$
}

The thirty-third annual meeting of the Semiotic Society of America meeting was held at the Renaissance Houston Hotel Greenway Plaza October 16-19, 2008 in conjunction with the University of St. Thomas in Houston, Texas. ${ }^{2}$ At this meeting Professor Susan Petrilli of the University of Bari, Italy was inscribed as the seventh Thomas A. Sebeok ${ }^{3}$ fellow. Professor Petrilli's Fellow address was delivered on October 17, 2008 12:45-14:00 in a plenary session. Her presentation, entitled "Semioethics and responsibility: Beyond specialisms, universalisms and humanisms", was an outstanding presentation on the topic semioethics and its importance to all of us in the twenty-first century. The large audience was entranced by her insightful observations.

Professor Petrilli was born in Adelaide, Australia and she received her doctorate from the University of Bari, Italy in 1993 in Language Theory and Sign Sciences.

Professor Petrilli's research in semiotics includes, but is not limited to, the following areas: biosemiotics, bio-ethics, semiotics and interpretation, and the work of Lady Victoria Welby. The following are some of her books in semiotics that are essential to an understanding of this interdiscipline: (1) Significs, semiotica, significazione (Petrilli 1988), (2) Materia segnica e interpretazione (Petrilli 1995), (3) Che cosa significa significare (Petrilli 1996), (4) Su Victoria Welby: Significs, e filosofia del linguaggio (Petrilli 1998b), (5) Teoria dei segni e del linguaggio (Petrilli 1998a), and (6) Percorsi della semiotica (Petrilli 2005). Her forthcoming work on Lady

\footnotetext{
1 Author's address: Frank Nuessel, Department of Classical and Modern Languages, University of Louisville, Louisville, KY, USA; email: fhnues01@louisville.edu.

2 See Cobley 2008.

3 November 9, 1920 - December 21, 2001.
} 
Victoria Welby (Petrilli forthcoming 2009) is highly anticipated. In addition, she has co-authored several additional works on semiotics: (1) Philosophy of Language: Art and Answerability in Mikhail Bakhtin (Ponzio, Petrilli 2000), (2) Thomas Sebeok and the Signs of Life (Ponzio, Petrilli 2001), (3) The Semiotic Animal (Deely, Petrilli, Ponzio 2005), (4) Reasoning with Emmanuel Levinas (Ponzio, Petrilli, Ponzio 2005), and (5) Semiotics Today: From Global Semiotics to Semioethics (Petrilli, Ponzio 2007).

Special mention is reserved for Professor Petrilli's recent book entitled Semiotics Unbounded: Interpretive Routes through the Open Network of Signs, co-authored with Professor Augusto Ponzio (Petrilli, Ponzio 2005), and reviewed by various scholars in the distinguished journal Semiotica (2008, volume 169(1/4): 223-360). This momentous volume is the second book ever to receive multiple reviews in that esteemed journal ${ }^{4}$ (nine in all by Ted Baenziger, Jeff Bernard, Paul Cobley, Vincent Colapietro, Floyd Merrell, Hisashi Muroi, József Nagy, Winfried Nöth, and Frank Nuessel). As Editorin-Chief of Semiotica, Marcel Danesi explains "[...] Semotics Unbounded fits into the tradition of key paradigmatic texts that require the attention of one and all" (Danesi 2008: 221). About this fact, there is no dispute.

Professor Petrilli's translations into Italian of many of Dr. Thomas A. Sebeok's influential works in semiotics merit mention here. They include The Sign and Its Masters (Sebeok 1985), I Think I Am a Verb (Sebeok 1990), Semiotics in the United States (Sebeok 1992), A Sign Is Just a Sign (Sebeok 1998), and Signs: An Introduction to Semiotics (Sebeok 2003).

\section{The American Journal of Semiotics}

For the first time in the history of the Thomas A. Sebeok Fellowship, a special issue of The American Journal of Semiotics (volume 24(4), 2008) entitled "Sign Crossroads in Global Perspective. Essays by Susan Petrilli $7^{\text {th }}$ SSA Sebeok Fellow" was made available for members in attendance at the annual SSA meeting. This issue contains the following all new essays by Professor Petrilli:

1. "Semioethics and responsibility: Beyond specialisms, universalisms and humanisms" (pp. 1-48).

2. "Working with interpreters of the 'Meaning of Meaning': International trends among $20^{\text {th }}$-century sign theorists" (pp. 49-88).

3. "The relation with Morris in Rossi-Landi's and Sebeok's approach to signs" (pp. 89-121).

4 The first being Jesper Hoffmeyer's Signs of Meaning in the Universe, reviewed in the special issue of Semiotica 120(3/4), 1998. 
4. "Iconicity and the origin of language: Charles S. Peirce (1839-1914) and Giorgio Fano (1885-1963)" (pp. 123-136) [This work is a revision of the Introduction for the English translation of Fano (1973) by Petrilli (1992).].

5. "Bodies and signs: For a typology of semiosic materiality" (pp. 137-158).

6. "Semiotic phenomenology of predicative judgement" (pp. 159-192) [This is a substantial revision of an earlier work by Petrilli (1999).].

7. "On communication: Contributions to the human sciences and to humanism from semiotics understood as semioethics" (pp. 193-236).

8. "Iconicity in translation: On similarity, alterity, and dialogism in the relation among signs" (pp. 237-302).

The articles in this special issue of The American Journal of Semiotics are representative of the various domains of semiotics in which Professor Petrilli works: (1) semioethics; (2) sign theory and semiosis; (3) iconicity and the origins of language; (4) semiotic materiality; (5) biosemiotics; (6) translation; (7) Lady Victoria Welby (1837-1912).

The final two pages (pp. 303-304) in The American Journal of Semiotics volume 24(4) contain information about the author. While these two pages suggest the extensive scope of Professor Petrilli's remarkable academic scholarship, they are, to be sure, incomplete. For a complete enumeration of Professor Petrilli's scholarly activity to date, the home page of her web site provides more information about her extraordinary work and achievements, including a listing of 31 books authored, co-authored, edited and co-edited since 1988, and 243 articles published since 1981 .

\section{Editorial boards and related matters}

Professor Petrilli serves as a member on editorial boards of some of the most esteemed journals in the field of semiotics today, namely, Semiotica (Journal of the International Association for Semiotic Studies), TTR, Traduction, Terminologie, Redaction. Études sur le texte et ses transformations, Journal of Biosemiotics, Russian Journal of Communication, International Journal for the Semiotics of Law, and Signs (International Journal of Semiotics). She is also a Co-Director of several book series including the following: (1) $\mathrm{Nel}$ segno (with Augusto Ponzio; (2) Gli strumenti (with Augusto Ponzio and Patrizia Calefato); (3) Di-segno-in-segno (with Augusto Ponzio and Cosimo Caputo); and (4) Segni-di-segni (with Augusto Ponzio and Cosimo Caputo).

She has been a Fellow of the International Communicology Institute, and an international visiting research scholar in the University of Adelaide, Australia and the Hawke Institute for Sustainable Societies, the University of South Australia.

$5 \quad$ At http://susanpetrilli.com/. 


\section{Previous Sebeok Fellows}

Dr. Petrilli joins an illustrious group of previous recipients of the prestigious Thomas A. Sebeok Fellow Award (see Deely 2005: 478-479 for more details about the previous recipients of this award, the sites of the Semiotic Society of America meeting, and the titles of the Sebeok Fellow Presentation), namely, (1) David Savan (posthumous award 1992); John Deely (1993); (3) Paul Bouissac (1996); (4) Jesper Hoffmeyer (2000); (5) Kalevi Kull (2003); and (6) Floyd Merrell (2005).

\section{References}

Cobley, Paul 2008. Specialization, semiosis, semiotics: the 33rd annual meeting of the Semiotic Society of America. Sign Systems Studies 36(2): 515-519.

Danesi, Marcel 2008. Semiotics unbounded: An editorial comment. Semiotica 169: 221-222.

Deely, John 2005. Floyd Merrell named sixth Thomas A. Sebeok Fellow of the Semiotic Society of America. Sign Systems Studies 33(2): 477-480.

Deely, John; Petrilli, Susan; Ponzio, Augusto 2005. The Semiotic Animal. Ottawa: Legas.

Fano, Giorgio 1973. Origini e natura de linguaggio. (Heilman, Luigi, ed. and introduction.) Turin: Giulio Einaudi.

Petrilli, Susan 1988. Significs, semiotica significazione. Bari: Adriatica.

- 1992. Iconicity and the origin of language. In: Fano, Giorgio, The Origins and Nature of Language. (Petrilli, Susan, trans.) Bloomington: Indiana University Press, xvii-xxvii. [Introduction to the translation of Fano 1973.]

- 1995. Materia segnica e interpretazione. Lecce: Milella.

- 1996. Che cosa significa significare? Bari: Edizioni dal Sud.

- 1998a. Su Victoria Welby: Significs, e filosofia del linguaggio. Napoli: Edizioni Scientifiche Italiane.

- 1998b. Teoria dei segni e del linguaggio. 2nd ed. Bari: Graphis.

- 1999. Semiotic phenomenology of predicative judgement. European Journal for Semiotic Studies [Special issue: Semiotic Studies in Bari] 11(4): 563-593.

- 2003. Sebeok's semiosic universe and global semiotics. Cybernetics and Human Knowing 10(1): 61-79.

- 2005. Percorsi della semiotica. Bari: Graphis.

- (ed.) (forthcoming, 2009). Significs: Writings (with Commentary) of Victoria Welby and the Significs Movement on Language and Communication.

Petrilli, Susan; Ponzio, Augusto 2005. Semiotics Unbounded: Interpretive Routes through the Open Network of Signs. Toronto: University of Toronto Press.

Petrilli, Susan; Ponzio, Augusto 2007. Semiotics Today: From Global Semiotics to Semioethics: A Dialogic Response. Ottawa: Legas.

Ponzio, Augusto; Petrilli, Susan; Ponzio, Julia 2005. Reasoning with Emmanuel Levinas. Ottawa: Legas. 
Ponzio, Augusto; Petrilli, Susan 2000. Philosophy of Language: Art and Answerability in Mikhail Bakhtin. Ottawa: Legas.

Ponzio, Augusto; Petrilli, Susan 2001. Thomas Sebeok and the Signs of Life. Cambridge: Icon Books.

Sebeok, Thomas A. 1985. Il segno e i suoi maestri. (Petrilli, Susan, trans.) Bari: Adriatica. [Orig: Sebeok, Thomas A. 1979. The Sign and Its Masters. Austin: University of Texas Press.]

- 1990. Penso di essere un verbo. (Petrilli, Susan, trans.) Palermo: Sellerio. [Orig: Sebeok, Thomas A. 1986. I Think I Am a Verb. New York: Plenum.]

- 1992. Sguardo sulla semiotica americana. (Petrilli, Susan, trans.) Milan: Bompiani. [Orig: Sebeok, Thomas A. 1991. Semiotics in the United States. Bloomington: Indiana University Press.]

- 1998. A Sign Is Just a Sign: La semiotica globale. (Petrilli, Susan, trans.) Milan: Spirali. [Orig: Sebeok, Thomas A. 1991. A Sign Is Just a Sign. Bloomington: Indiana University Press.]

- 2003. Segni: Introduzione alla semiotica. (Petrilli, Susan, trans.) Roma: Carocci. [Orig: Sebeok, Thomas A. 2001. Signs: An Introduction to Semiotics. 2nd ed. Toronto: University of Toronto Press.] 
526 Frank Nuessel 